\title{
OBITUARY: DR. LOUIS CHAUVOIS
}

The recent passing of Louis Chauvois in Paris, will fill many an English heart with sorrow. For he was the cultured French gentleman at his best, and his courteous manner and his beautiful powers of speech were something never to be forgotten.

When he and his charming grand-daughter attended the tercentenary commemoration in London of the death of William Harvey in 1957, they truly dominated that memorable conference. We all remember his comparison of the physiological mechanism of the human body to the motor-car, and of the foetus to a submarine with a very long schnorkel: umbilical cord, placenta, uterine artery, aorta, left ventricle, vena cava, right atrium, right ventricle, and pulmonary artery to the alveoli, bronchi, trachea and the open air. At that time he was fresh from his fine life of William Harvey, which had a tremendous sale in France, as did the English edition also (with foreword by Sir Zachary Cope) here and in America. He was a great worshipper of Harvey and his discovery and he admired especially the two letters to Riolan which Harvey wrote fifteen years after De Motu Cordis. He seemed always anxious to remedy and redress the animosity and opposition that Harvey's discovery aroused in France.

Three years ago when he was eighty-eight years old he wrote and produced a play in the geriatric hospital in which he was a very active resident. I had the good fortune to attend this play, and in it he introduced Louis XIV, Molière, Boileau, Racine and La Fontaine, five laymen who fought for Harvey and his discovery, and made it the foundation of medical teaching in the Académie Royale which Louis XIV established at that time. The play was attended by all the medical historians of Paris, and there was standing room only.

His historical knowledge, especially that concerning medicine, was formidable. His knowledge of Greek and Latin was complete, and I remember his speaking in fluent Latin to two Russian delegates at the Harveian conference, as that was their only common language. He could read Harvey's Latin, and he translated Laënnec, and said that his was much worse. He wrote much, and every morning at eight he would leave his geriatric hospital in Auteuil and make his way to museum or library by Metro to study material for his writings. His greatest triumph was at the age of eighty-six to publish an excellent life of a great and practically unknown genius, Zenobie Gramme, the first man to make an electric dynamo.

The Harveian Society paid him a great honour in 1967, when 140 members made the journey to Paris to celebrate a feate d'honneur to him alone at which he spoke wonderfully and clearly.

He was associated with the great d'Arsonval as assistant and partner for many years. They had a great mutual regard for each other, and d'Arsonval presented Chauvois with the tweed trilby hat which Clémenceau always wore and gave to him. Clémenceau, who was a doctor, was the forceful Premier of France during the First World War and he kept up the morale of the French people as Lloyd George did that of the English. Chauvois always wore Clémenceau's hat.

Chauvois spent many years searching for the electrical equipment which d'Arsonval used in his momentous and remarkable discovery of the diathermy current. Finally 


\section{News, Notes and Queries}

he discovered it all in that amazing repository founded by Henry Wellcome in the Euston Road.

Chauvois was a Breton (his father was a pharmacist), and he returned to his beloved Brittany after ninety-one years of brilliant and fruitful life, to be buried in the little seaside village of Rothieneuf, which he always deeply loved.

It will be many years before such a kind and wonderful man is forgotten in our country.

A. Dickson Wright

WALTER CHARLETON'S 'ORATIO ANNIVERSARIA’ 1701. LONDON, 1704.

The Librarian of the Royal College of Physicians, 11 St. Andrew's Place, London, NW1 4LE, would be glad to hear from anyone having a copy of Walter Charleton's Harveian Oration 1701, or knowing where one is to be found. The only evidence so far for its publication is in Arber's Term catalogues (vol. 3, 1697-1709. London, 1906. p.401). 